\title{
Multidrug resistance-associated protein-1 (MRP1) genetic variants, MRP1 protein levels and severity of COPD
}

\author{
Simona E Budulac 1 , Dirkje S Postma2 , Pieter S Hiemstra³, Lisette IZ Kunz ${ }^{3}$, Mateusz Siedlinski1 , Henriette A Smit4, \\ Judith M Vonk1, Bea Rutgers5 ${ }^{5}$ Wim Timens ${ }^{5}$, H Marike Boezen*1 and the Groningen Leiden Universities \\ Corticosteroids in Obstructive Lung Disease (GLUCOLD) study group
}

\begin{abstract}
Background: Multidrug resistance-associated protein-1 (MRP1) protects against oxidative stress and toxic compounds generated by cigarette smoking, which is the main risk factor for chronic obstructive pulmonary disease (COPD). We have previously shown that single nucleotide polymorphisms (SNPs) in MRP1 significantly associate with level of FEV 1 in two independent population based cohorts. The aim of our study was to assess the associations of MRP1 SNPs with FEV 1 level, MRP1 protein levels and inflammatory markers in bronchial biopsies and sputum of COPD patients.

Methods: Five SNPs (rs212093, rs4148382, rs504348, rs4781699, rs35621) in MRP1 were genotyped in 110 COPD patients. The effects of MRP1 SNPs were analyzed using linear regression models.

Results: One SNP, rs212093 was significantly associated with a higher FEV level and less airway wall inflammation. Another SNP, rs4148382 was significantly associated with a lower FEV 1 level, higher number of inflammatory cells in induced sputum and with a higher MRP1 protein level in bronchial biopsies.

Conclusions: This is the first study linking MRP1 SNPs with lung function and inflammatory markers in COPD patients, suggesting a role of MRP1 SNPs in the severity of COPD in addition to their association with MRP1 protein level in bronchial biopsies.
\end{abstract}

\section{Background}

Chronic obstructive pulmonary disease (COPD) is an inflammatory lung disease associated with an influx of neutrophils, macrophages and CD8 ${ }^{+}$T-lymphocytes in the airways and lung tissue[1]. Smoking generates oxidative stress resulting from an oxidant - antioxidant imbalance, and oxidative stress markers are increased in airspaces, blood and urine of smokers and COPD patients[2]. Oxidative stress can be reduced by members of the ATP-binding cassette $(\mathrm{ABC})$ superfamily of transporters. One such a transporter is multidrug resistance-

* Correspondence: h.m.boezen@epi.umcg.nl

1 Department of Epidemiology, University Medical Center Groningen,

University of Groningen, Groningen, the Netherlands

Full list of author information is available at the end of the article associated protein-1, MRP1, (official name $A B C C 1, A B C$ subfamily $C$, member 1 ) that plays an important role in normal lung physiology by protecting against toxic xenobiotics and endogenous metabolites[3].

MRP1 was first detected in small cell lung cancer. It has been shown to be highly expressed in the normal human lung $[4,5]$ and particularly at the basolateral side of human bronchial epithelial cells[6]. Interestingly, we have previously shown that MRP1 is less expressed in bronchial epithelium of COPD patients compared to healthy subjects[7]. Mrp1/Mdr1a/1b triple knock-out mice had a poor ability for smoke-induced IL-8 production compared with wild type mice, which associated with almost complete absence of inflammatory cells in response to cigarette smoke[8]. An additional study demonstrated 
that cigarette smoke extract inhibits MRP1 activity in bronchial epithelial cells in vitro[9]. Thus there is a clear role for MRP1 in COPD.

A total of 51 single nucleotide polymorphisms (SNPs) with a minor allele frequency (MAF) $>5 \%$ are required to tag the entire MRP1 gene in Caucasians[10]. We have shown that two SNPs in MRP1 significantly associate with a lower or higher level of $\mathrm{FEV}_{1}$ in two independent population-based cohorts. Two additional SNPs had a significant effect of the same, negative magnitude on the level or decline of $\mathrm{FEV}_{1}$. One SNP was a significant predictor of COPD in the general population [11].

So far, no study has focused on the relation between MRP1 polymorphisms and the level of lung function, inflammatory markers and MRP1 protein in lung tissue of individuals with established COPD. We had the unique opportunity to do so in a recently finished, two center trial in COPD that amongst others studies inflammatory markers in bronchial biopsies and induced sputum[12]. Furthermore, we assessed whether MRP1 protein levels in bronchial biopsies of COPD patients are associated with MRP1 SNPs.

\section{Methods}

\section{Study populations}

COPD patients

We included 114 patients with COPD who participated in a two-center trial (Groningen Leiden Universities and Corticosteroids in Obstructive Lung Disease; GLUCOLD study). Patient characteristics and methods have been described in detail previously[12]. In brief, all patients had irreversible airflow limitation and chronic respiratory symptoms[13]. Included patients had neither used a course of oral steroids during the previous 3 months, nor maintenance treatment with inhaled or oral steroids during the previous 6 months. They were current or exsmokers with a smoking history of $\geq 10$ packyears, aged between 45 and 75 years without a history of asthma. The study was approved by the medical ethics committees of the University Medical Centers of Leiden and Groningen. All patients gave their written informed consent.

\section{Controls}

To verify the differences of MRP1 levels in bronchial biopsies between COPD patients and healthy subjects, we included 37 subjects as controls, of which 28 were previously recruited in order to participate in a smoking cessation program[14]. They were symptomatic and asymptomatic smokers according to the ATS-ERS (American Thoracic Society-European Respiratory Society) guidelines [15] and met the following criteria: 45-75 years of age, $>10$ pack years of smoking, $\mathrm{FEV}_{1} / \mathrm{FVC}$ pre and post bronchodilator $>70 \%$, no use of inhaled or oral corticosteroids in the previous 6 months, no sign of atopy, no respiratory tract infections one month prior to the study and none of the participants had any co-morbidity[14]. The remaining 9 subjects were included as controls with an $\mathrm{FEV}_{1} / \mathrm{FVC}$ pre and post bronchodilator $>70 \%$ and $\mathrm{FEV}_{1}>80 \%$ predicted.

We used an additional control group from the general population-based cohort (Doetinchem) [16] to check for the differences in genotype distributions between COPD patients and general population (Additional file 1).

\section{Clinical characteristics}

Lung function and reversibility to salbutamol were measured as described previously for COPD patients [12] and for controls[14].

Sputum induction and processing were performed as described previously [12] according to a validated technique[17]. Details on biopsy processing, immunohistology and analysis have been published previously[18]. In brief, we collected the two best morphological biopsies out of four paraffin embedded biopsies per patient and used specific antibodies against $\mathrm{T}$ lymphocytes (CD3, CD4 and CD8), macrophages (CD68), neutrophil elastase (NE), mast cell tryptase (AA1) and eosinophils (EG2) (Additional file 1).

\section{Selection of the MRP1 tagging SNPs and genotyping}

We selected SNPs based on our previous results showing a significant association of 5 MRP1 SNPs (rs212093, rs4148382, rs35621, rs4781699 and rs504348) with the $\mathrm{FEV}_{1}$ level and/or annual $\mathrm{FEV}_{1}$ change in two independent population-based cohorts [11]. The rs504348 SNP results in a significant increase in $M R P 1$ promoter activity in vitro[19]. Genotyping was performed by K-Bioscience (UK) using their patent-protected competitive allele specific PCR system (KASPar).

\section{Biopsies and immunohistochemistry on bronchial biopsies from COPD patients and controls}

Details on bronchial biopsy collection and processing are described in the data supplement. Four paraffin-embedded biopsies were cut in $4 \mu \mathrm{m}$ thick sections and haematoxylin/eosin staining was used for evaluation and selection of the best morphological biopsy per subject for analysis (without crush artefacts, large blood clots, or only epithelial scrapings). The staining was performed on one paraffin section of $4 \mu \mathrm{m}$ per subject with monoclonal antibody MRPr1 for MRP1 (Santa Cruz, California, USA). Details on immunohistochemical staining are described in Additional file 1.

\section{Evaluation of immunohistochemistry on bronchial biopsies} from COPD patients and controls

Evaluation of different types of epithelium was performed separately (i.e. basal epithelium, squamous metaplasia, intact epithelium). For the current study, intact bronchial epithelium was selected for analysis. 
MRP1 protein was scored for staining intensity in intact epithelium of bronchial biopsies with a semi quantitative score: 0 = no staining; 1 = weak; $2=$ moderate; $3=$ strong. MRP1 intensity scores for intact epithelium were available from 80 bronchial biopsies of subjects with COPD and 26 bronchial biopsies of controls. Due to the fact that there were only 3 individuals with no immunohistochemical expression of MRP1, the MRP1 intensity was categorised in 3 groups: 1 = weak staining, $2=$ moderate staining and 3 = strong staining. Two observers (S.B. and W.T.) performed all evaluations of bronchial biopsies individually, in a blinded manner. Most sections stained variable for MRP1 in epithelium and parts with the most intense staining were evaluated for scoring.

\section{Statistics}

Numbers of inflammatory cells in bronchial biopsies and induced sputum were log transformed to achieve a normal distribution. Linear regression analyses were performed to investigate the association of MRP1 SNPs with $\mathrm{FEV}_{1}$ level and inflammatory cells (natural logarithm) in bronchial biopsies and induced sputum. Independent variables included in the model were age, gender, height, packyears and genotypes. To assess the effect of SNPs on $\mathrm{FEV}_{1}$ level and cell numbers in bronchial biopsies and induced sputum we used the following genetic models:

- General: heterozygote and homozygote variants coded separately as dummy variables and compared to the homozygote wild type

- Dominant: heterozygote and homozygote variants pooled and compared to the homozygote wild type

Differences in MRP1 staining intensity between biopsies of COPD patients and controls and according to $M R P 1$ SNPs were analyzed using Chi-square tests. Analyses were performed using SPSS version 16.0 for Windows and values of $\mathrm{p}<0.05$ (tested 2-sided) were considered statistically significant.

\section{Results}

The clinical characteristics of COPD patients and controls are presented in Table 1.

DNA was available from 110 out of 114 COPD patients and from 37 controls. All 5 MRP1 SNPs were in Hardy Weinberg Equilibrium (HWE, p > 0.05) and were not highly correlated with each other (the highest $r^{2}$ in our population is 0.34) (See figure S1 in Additional file 2). There were no significant differences in genotype distributions between the COPD patients and the general population-based control cohort (Additional file 1). Likewise, there were no significant differences in genotype distributions between the COPD patients and controls (Table 2).
Table 3 shows the number and the percentage of inflammatory cells in bronchial biopsies and induced sputum from the COPD patients.

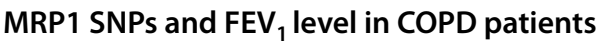

In a general model, individuals who were homozygote mutant (GG) for rs212093 had a significantly higher FEV than wild type (AA) individuals, as reflected by a regression coefficient $B$ value (95\% CI, confidence interval) of $222 \mathrm{ml}$ (48 $\mathrm{ml}$ to $396 \mathrm{ml}$ ); $\mathrm{p}=0.013$. Heterozygote (GA) individuals for rs4148382 had a significantly lower $\mathrm{FEV}_{1}$ than wild type (GG) individuals $(-215 \mathrm{ml}(-356 \mathrm{ml}$ to -75 $\mathrm{ml}) ; \mathrm{p}=0.003$ ). None of the other 3 SNPs (rs504348, rs4781699 and rs35621) was significantly associated with the $\mathrm{FEV}_{1}$ level (Figure 1). Additional adjustment for current smoking status did not change the size or significance of the effect estimates of the genotypes on level of $\mathrm{FEV}_{1}$.

\section{MRP1 SNPs and inflammatory cells in bronchial biopsies in COPD patients}

Homozygote mutant (GG) individuals for rs212093 had a significantly lower number of plasma cells $(-0.72(-1.27$ to $-0.18) ; \mathrm{p}=0.01)$, neutrophils $(-0.63(-1.16$ to -0.09$) ; \mathrm{p}=$ $0.02)$ and macrophages $(-0.61(-1.07$ to -0.15$) ; \mathrm{p}=0.01)$ in bronchial biopsies than wild type (AA) individuals (Figures $2 \mathrm{a}, \mathrm{b}$ and $2 \mathrm{c}$, respectively). Individuals who were heterozygote (AG) for rs212093 had lower numbers of mast cells than wild type (AA) individuals $(-0.25(-0.47$ to -0.03); $\mathrm{p}=0.02$ ) (Figure $2 \mathrm{~d}$ ).

Minor allele carriers (GT/TT) for rs4781699 had significantly lower numbers of macrophages $(-0.34$ (-0.67 to $0.02) ; \mathrm{p}=0.04$ ) than wild type (GG) individuals (Figure 3 ).

The genotypes for the other two SNPs (rs4148382 and rs35621) were not significantly associated with any of the inflammatory cells in the bronchial biopsies.

\section{MRP1 SNPs and inflammatory cells in sputum in COPD patients}

Heterozygote (GA) individuals for rs4148382 had a significantly higher total cell count $(0.59(0.11$ to 1.07$) \mathrm{p}=$ $0.01)$ and neutrophils (0.61 (0.06 to 1.16$) ; \mathrm{p}=0.03)$ in sputum compared to wild type (GG) individuals. None of the other SNPs was significantly associated with inflammatory cells in sputum.

Additional adjustment for current smoking status did not change the size or significance of the effect estimates of the genotypes on inflammatory cells in bronchial biopsies and in induced sputum.

Detailed data on the MRP1 genotypes and inflammatory cells in bronchial biopsies and induced sputum are presented in the Additional file 1. 
Table 1: Clinical characteristics of COPD patients and controls with airway biopsy available.

\begin{tabular}{|c|c|c|}
\hline & COPD patients $(n=114)$ & Controls $(n=37)$ \\
\hline Males, n (\%) & $99(86.8)$ & $16(43.2)$ \\
\hline Age (years) & $61.6 \pm 7.7$ & $52.3 \pm 5.5$ \\
\hline Height (cm) & $175.5 \pm 7.8$ & $172.8 \pm 10$ \\
\hline Packyears & $41.8(31.2-54.7)$ & $25.4(20.2-35.0)$ \\
\hline Current smoker, n (\%) & $72(63.2)$ & $30(81.1)$ \\
\hline $\mathrm{FEV}_{1} / \mathrm{FVC}(\%)$ & $49.5 \pm 8.8$ & $77.2 \pm 6.1$ \\
\hline $\mathrm{FEV}_{1}(\mathrm{~L})$ & $1.8 \pm 0.4$ & $3.2 \pm 0.8$ \\
\hline $\mathrm{FEV}_{1} \%$ pred.* & $56 \pm 10$ & $100 \pm 14$ \\
\hline MRP1 level \#, $\mathrm{n}$ & 80 & 26 \\
\hline
\end{tabular}

\section{MRP1 protein levels in COPD patients and controls}

There were no significant differences in MRP1 protein levels between COPD patients and controls.

Heterozygote (GA) individuals for rs4148382 had a significantly higher MRP1 protein level than wild type (GG) individuals in COPD patients $(p=0.026)$ (Figure 4a) and in the control group minor allele carriers (GA/AA) for rs4148382 had a significantly higher MRP1 protein level than wild type (GG) individuals $(\mathrm{p}=0.037)$ (Figure $4 \mathrm{~b}$ ).

Minor allele carriers (GT/TT) for rs4781699 had significantly lower MRP1 protein level than wild type (GG) individuals in COPD patients $(\mathrm{p}=0.036)$ (Figure 4c), but there was no significant difference in MRP1 protein level in the control group (Figure $4 \mathrm{~d}$ ).

None of the other 3 SNPs (rs212093, rs504348 and rs35621) associated significantly with MRP1 protein levels. Levels of MRP1 were not related to lung function parameters, inflammatory cells in bronchial biopsies or number of packyears.

\section{Discussion}

This is the first study linking MRP1 SNPs with the severity of COPD and additionally with the intensity of MRP1 staining in bronchial biopsies. Our results suggest a role of MRP1 in COPD severity, as indicated by the associations of rs212093 genotypes with a higher level of FEV and less inflammatory cells in bronchial biopsies. Addi- tionally, the SNPs rs504348 and rs4781699 were associated with less airway wall inflammation and rs4148382 with a lower $\mathrm{FEV}_{1}$ level and increased sputum cell numbers. Moreover, the before mentioned SNPs rs4148382 and rs4781699 were associated with respectively higher and lower levels of MRP1 protein in bronchial biopsies of COPD patients (see summary of the results in Figure 5).

Since first described in 1992 [4], a fair amount of data on the structure, substrate, function, and regulation of this transporter has been gathered. MRP1 is a member of the human ATP-binding cassette superfamily of transporters which regulates the traffic of molecules across cell membranes. The MRP1 pump confers resistance to several chemotherapeutic agents including vincristine, daunorubicin and methotrexate[20,21]. In addition to protecting cells within the body against drugs, environmental toxins and heavy metals, MRP1 has been suggested to be involved in the cellular oxidative defence system and inflammation [22,23], both being important in COPD development and progression.

We showed that the MRP1 polymorphism rs212093 was significantly associated with a higher $\mathrm{FEV}_{1}$ level. In line with this, rs212093 SNP was associated with lower numbers of plasma cells, macrophages, neutrophils and mast cells in bronchial biopsies, cells implicated in COPD previously. Increased numbers of neutrophils have been reported in bronchial biopsies of smokers with airflow 
Table 2: Prevalence of MRP1 SNPs in COPD patients and controls.

\begin{tabular}{|c|c|c|c|c|}
\hline & & $\begin{array}{l}\text { COPD patients } \\
n=110(\%)\end{array}$ & Controls $\mathrm{n}=\mathbf{3 7}(\%)$ & p value \\
\hline \multirow[t]{3}{*}{ rs212093 } & AA & $37(33.9)$ & $8(25.0)$ & 0.55 \\
\hline & AG & $50(45.9)$ & $18(56.2)$ & \\
\hline & GG & $22(20,2)$ & $6(18.8)$ & \\
\hline \multirow[t]{3}{*}{ rs4148382 } & GG & $83(76.1)$ & $29(82.8)$ & 0.12 \\
\hline & $\mathrm{GA}$ & $26(23.9)$ & $5(14.3)$ & \\
\hline & AA & - & $1(2.9)$ & \\
\hline \multirow[t]{3}{*}{ rs504348 } & $\mathrm{CC}$ & $78(72.2)$ & $22(71.0)$ & 0.23 \\
\hline & CG & $27(25.0)$ & $6(19.3)$ & \\
\hline & GG & $3(2.8)$ & $3(9.7)$ & \\
\hline \multirow[t]{3}{*}{ rs4781699 } & GG & $58(52.7)$ & $21(61.8)$ & 0.47 \\
\hline & GT & $45(40.9)$ & $10(29.4)$ & \\
\hline & $\pi$ & $7(6.4)$ & $3(8.8)$ & \\
\hline \multirow[t]{3}{*}{ rs35621 } & $\mathrm{CC}$ & $89(80.9)$ & $30(85.7)$ & 0.74 \\
\hline & $\mathrm{CT}$ & $20(18.2)$ & $5(14.3)$ & \\
\hline & $\pi$ & $1(0.9)$ & - & \\
\hline
\end{tabular}

Different numbers for the SNP genotypes are due to missing genotype data

$\mathrm{SNP}=$ single nucleotide polymorphism; $M R P 1=$ multidrug resistance-associated protein-1

limitation, an increase that was associated with a lower $\mathrm{FEV}_{1}$ [24]. Neutrophils and macrophages release proteolytic enzymes and generate oxidants, which cause tissue damage as well as cytokines and chemokines that can potentiate inflammation and trigger an immune response. We previously reported a larger number of $\mathrm{B}$ lymphocytes in bronchial biopsies of patients with COPD than in controls without airflow limitation[25]. Furthermore, epithelial cells of smokers with COPD contain higher macrophage and mast cell numbers than smokers without COPD[26]. In a triple knock-out mouse model, we previously demonstrated that the inflammatory response to inhalation of cigarette smoke is reduced when MRP1 is absent[8]. Linking previously reported increased airway wall inflammation in COPD with genetic variants of $M R P 1$ we found rs 212093 to be associated with lower numbers of inflammatory cells in bronchial biopsies, therefore, this SNP might play a protective role in COPD. This SNP located in 3'region is known to be in complete linkage disequilibrium with rs129081 located in the 3' untranslated region [10] and therefore this polymorphism might be involved in the regulation of MRP1 mRNA stability[11].

One could raise the issue of multiple testing and that we should have adjusted for this in our analyses, but we feel that applying a sequential (classical) Bonferroni correction is not appropriate in the current dataset for a number of reasons[27]. Firstly, our choice for the current 
Table 3: The number of inflammatory cells in bronchial biopsies and induced sputum of COPD patients

\begin{tabular}{|c|c|c|}
\hline Bronchial biopsies & $\begin{array}{l}\text { Absolute numbers per } 0.1 \mathrm{~mm} 2 \text { sub-epithe- } \\
\text { lial area }\end{array}$ & \\
\hline CD3 & $123.5(69.2-182.5)$ & \\
\hline CD4 & $48.0(27.7-72.0)$ & \\
\hline CD8 & $21.5(11.0-37.2)$ & \\
\hline Plasma cells & $8.5(3.5-14.5)$ & \\
\hline Mast cells & $26.5(19.0-34.5)$ & \\
\hline Macrophages & $8.5(4.5-13.0)$ & \\
\hline Neutrophils & $4.0(2.0-8.4)$ & \\
\hline Eosinophils & $1.5(0.5-4.2)$ & \\
\hline Induced sputum & Absolute numbers $\left(10^{4} / \mathrm{ml}\right)$ & Percentage (\%) \\
\hline Total cell count* & $139.7(77.9-311.3)$ & \\
\hline Neutrophils & $101.6(46.8$ - 228.5) & $72.8(59.9-81.7)$ \\
\hline Macrophages & $31.1(17.9-61.1)$ & $22.1(14.8-33.2)$ \\
\hline Eosinophils & $1.3(0.4-4.5)$ & $1.1(0.3-2.2)$ \\
\hline Lymphocytes & $2.2(1.1-6.8)$ & $1.7(1.2-2.3)$ \\
\hline Epithelial cells & $1.4(0.6-3.4)$ & $1.0(0.3-2.3)$ \\
\hline
\end{tabular}

Data are presented as median ( $25^{\text {th }}-75^{\text {th }}$ percentile)

*Total cell count refers to the number of non-squamous cells in induced sputum

study was explicitly driven by our previous findings, suggesting that there might be associations between MRP1 SNPs and COPD severity. Thus, we explicitly hypothesized on the main outcome variables on forehand. Secondly, a Bonferroni correction would not take into account the potential clustering of outcome variables, which might occur jointly at high or low levels, e.g. a Pearson's correlation coefficient $r=0.79$ for macrophages and lymphocytes in induced sputum, or are defined as each others ratios[27]. This suggests one might preferentially test a cluster of outcome variables as "one outcome variable" rather than test all variables separately.
It has been shown previously that higher neutrophil percentages in induced sputum correlate with lower $\mathrm{FEV}_{1}$ levels [28], therefore it is of interest that rs4148382, located in 3'region of MRP1, is associated significantly with higher total cells counts and neutrophils in induced sputum and lower $\mathrm{FEV}_{1}$ level. The association with total cell counts might be driven by the neutrophils which represent $72 \%$ of the total cells in induced sputum. The functional consequence of this particular SNP is not known so far and it is not known whether any functional polymorphism is in linkage disequilibrium with it. This polymorphism is located closely to the 5'end of the MRP6 which maps also on chromosome 16. However, MRP6 mRNA is 


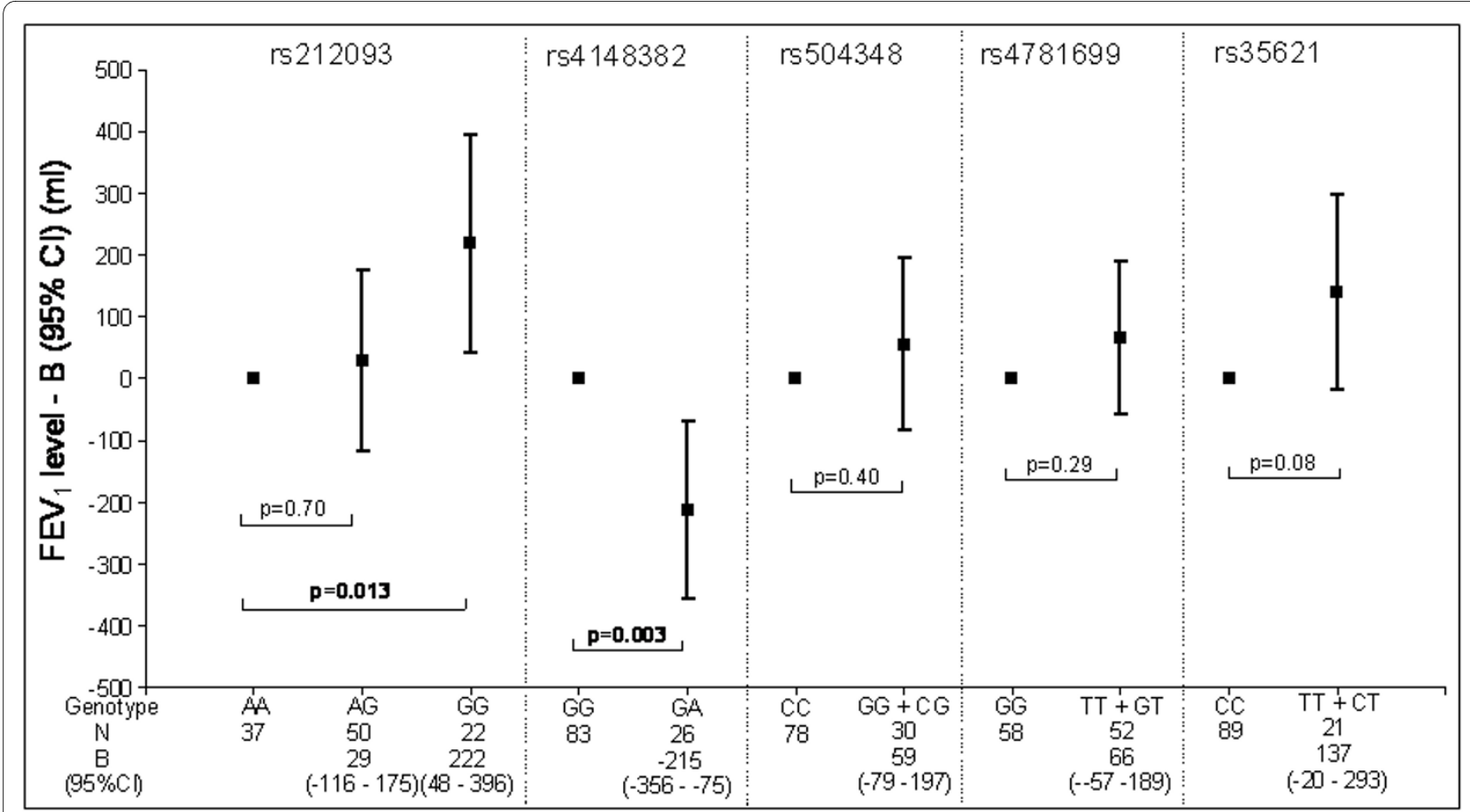

Figure 1 Estimated effects of $M R P 1$ genotypes on level of $\mathrm{FEV}_{1}$ in $\mathrm{COPD}_{\text {patients. }} \mathrm{FEV} \mathrm{V}_{1}=$ forced expiratory volume in one second. $\mathrm{N}=\mathrm{Number}$ of individuals. Squares represent the regression coefficient (B) and vertical bars represent $95 \%$ confidence interval (CI). Wild type was set to zero as the reference category. The analyses are adjusted for age, gender, height and packyears.

moderately present in human lung extracts [29] and highly expressed in the liver and kidney [6], which might suggest indeed that the effect of this particular SNP is within MRP1 and not MRP6. How this SNP functionally contributes to COPD severity has to be further unravelled in future studies.

The observed effects in the current study appear to be opposite to previous findings in the same general population as described by Siedlinski et al[11]. In the current study, which extends the previous findings, we observed that rs4148382 associated with a lower $\mathrm{FEV}_{1}$ level in COPD patients, whereas in the general population from the Doetinchem study rs4148382 associated with a higher $\mathrm{FEV}_{1}$ level [11]. With respect to these findings it is worth mentioning that the present study was not designed to compare the direction or magnitude of effect estimates between the COPD patients and general population with respect to $\mathrm{FEV}_{1}$ and genetic factors. The opposite effects are likely due to the fact that we selected a COPD subset of the Doetinchem general population for the current study by matching on the clinical characteristics age, number of packyears and $\mathrm{FEV}_{1} / \mathrm{FVC}<70 \%$. Although both groups had almost the same number of packyears (median $25^{\text {th }}-75^{\text {th }}$ percentile) $(40(34.1-48.7)$ vs. 41.8 (31.2 -54.7)), the matched COPD subset in the general population had a higher lung function (mean $\mathrm{FEV}_{1} \%$ pre- dicted $(\mathrm{SD})=79.7$ (13.4)) than our current COPD patients $(49.5(8.8))$. This suggests that the COPD subset of subjects from the Doetinchem study who, fulfilled the GOLD criteria of COPD, might be less susceptible to cigarette smoke and COPD development. Therefore, the patients included in the current study with established COPD were probably not comparable with the heavy smokers from the general population based control cohort (Doetinchem).

Additionally, we have calculated the haplotypes of MRP1 and assessed the effects of these haplotypes on $\mathrm{FEV}_{1}$ level and inflammatory cells in bronchial biopsies and induced sputum. We observed that the effects of MRP1 haplotypes are due to the specific SNP constituting these haplotypes, and therefore didn't add new information. Details on the MRP1 haplotypes are presented in the Additional file 1.

Decreased or increased functional MRP1 expression may have a high impact on development and/or progression of lung diseases and protection against air pollution and inhaled toxic compounds such as present in cigarette smoke[6,7,30]. One of our earlier studies showed that the MRP1 intensity in bronchial biopsies of COPD patients was lower compared to healthy individuals[7]. How can we reconcile this with our current findings of MRP1 staining in COPD patients and controls? One option is 


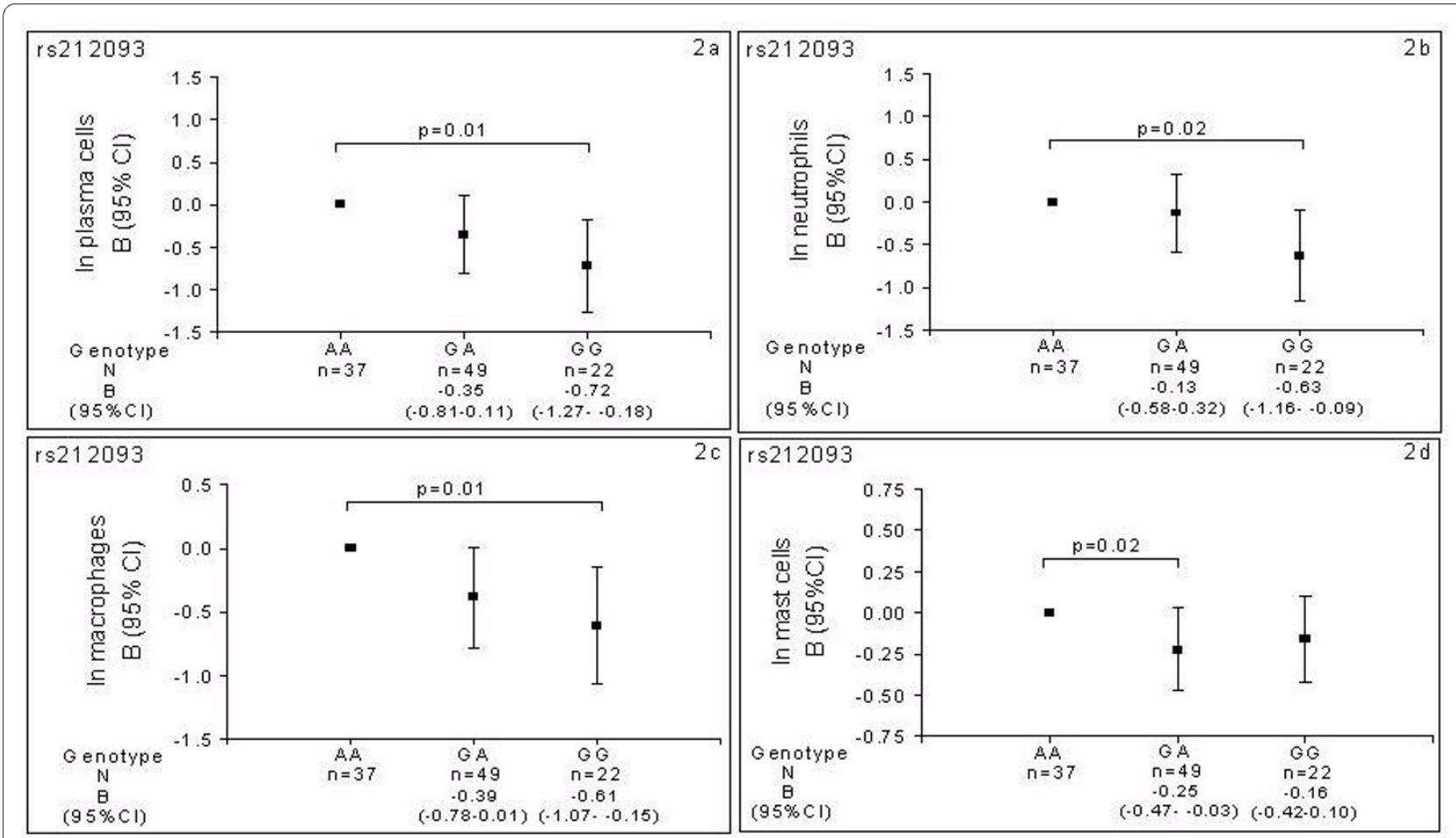

Figure 2 Estimated effects of MRP1 genotypes on inflammatory cells in bronchial biopsies of COPD patients. 2a: Number of plasma cells according to rs212093 genotype. 2b: Number of neutrophils according to rs212093 genotype. 2c: Number of mast cells according to rs212093 genotype. 2d: Number of macrophages according to for rs212093 genotype.

that this might be due to differences in staining between paraffin and frozen biopsies[31]. More important, it might be due to underlying differences of MRP1 genotyping distribution in the two populations. It appeared that the previous low intensity of MRP1 staining was driven

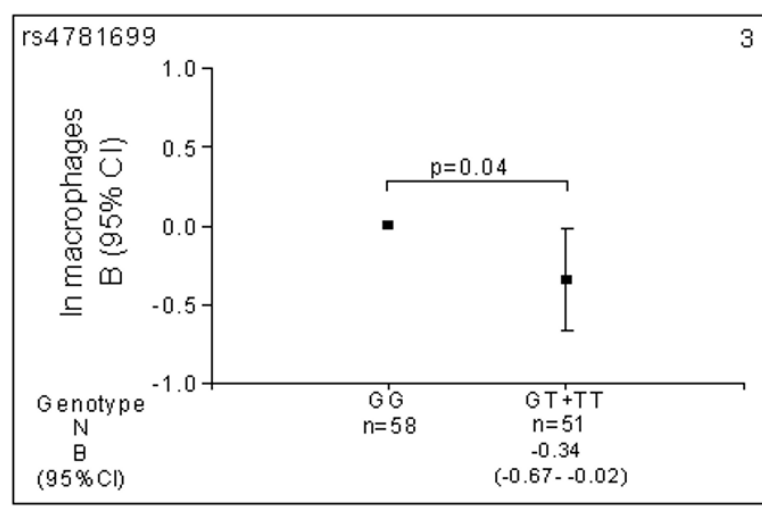

Figure 3 Estimated effects of MRP1 genotypes on inflammatory cells in bronchial biopsies of COPD patients. Number of macrophages according to rs4781699 genotype. $\mathrm{N}$ = number of individuals. Data are presented as natural logarithm of each type of cells in bronchial biopsies. Different numbers for the SNP genotypes are due to missing data on genotype or inflammatory cells. Squares represent the regression coefficient (B) and vertical bars the $95 \%$ confidence interval $(\mathrm{Cl})$. Wild type was set to zero as the reference category. The analyses are adjusted for age, gender and packyears. by wild type individuals [7] and if we would have known this at that time, it might have had a different impact on the interpretation of the results. MRP1 is an essential pump for glutathione (GSH) - conjugates such as the inflammatory mediator leukotriene C4 (LTC4) as well as substrates in the presence of GSH (i.e. glutathione disulphide, GSSG) [32], thereby decreasing intracellular concentrations of toxic compounds. Given the rarity of homozygote mutant (AA) individuals for rs4148382 all the conclusions about this SNP are drawn based on the heterozygote (GA) individuals in COPD patients. It might be that in particular individuals who are heterozygote for rs4148382 SNP can have a locally high MRP1 protein level which therefore might lead to more severe inflammation at that site. Clearly, further research needs to investigate this approach in a larger sample of subjects with or without COPD.

\section{Conclusions}

In conclusion, our study is the first to demonstrate that MRP1 plays a role in COPD severity, given the association of polymorphisms in $M R P 1$ with airway wall inflammation, the level of lung function and moreover MRP1 protein levels in subjects with established COPD. This is an important step forward linking $M R P 1$ polymorphisms with the pathophysiology of COPD. 


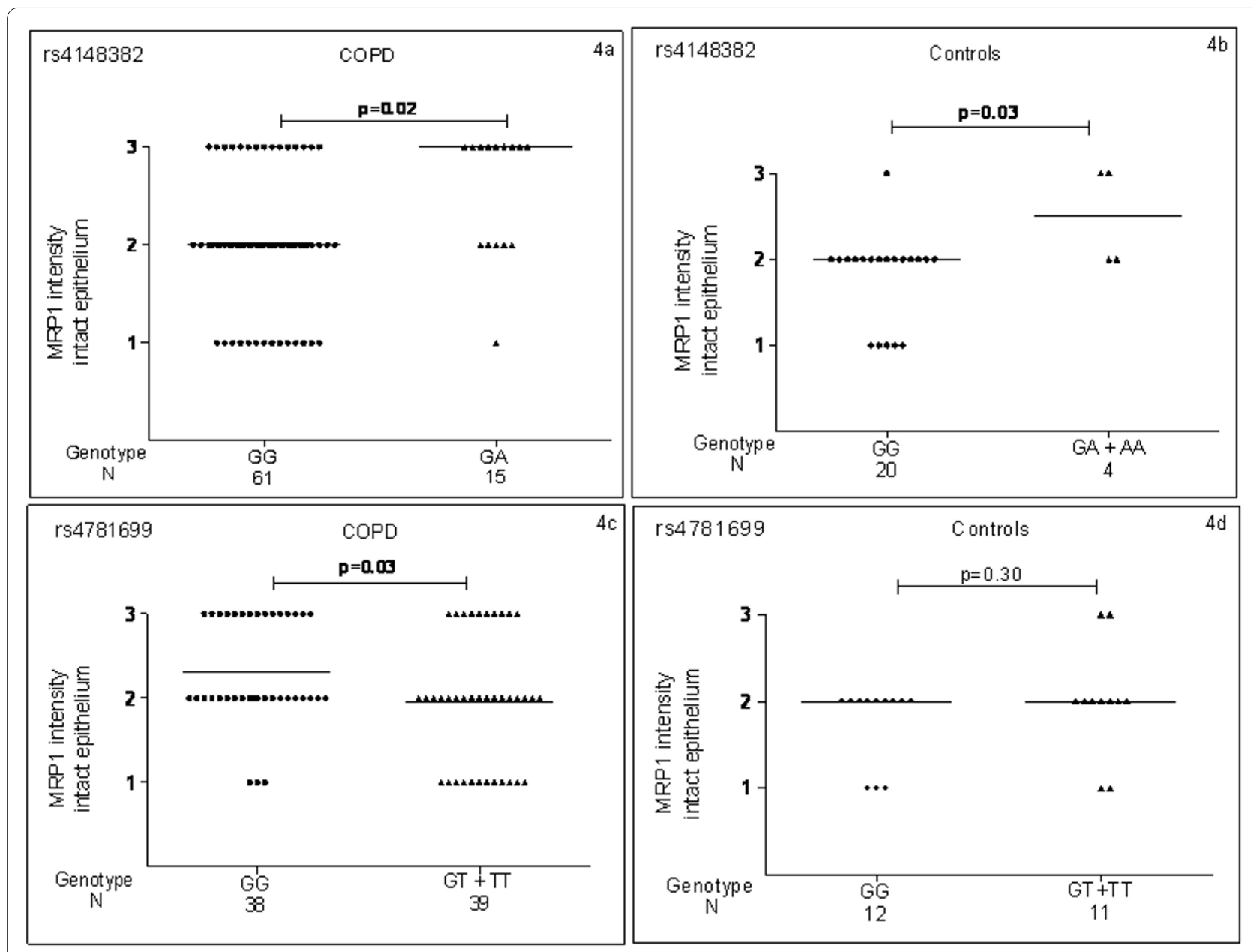

Figure 4 MRP1 SNPs and MRP1 protein levels of COPD patients and controls. 4a: MRP1 protein levels according to rs4148382 genotype in COPD patients. 4b: MRP1 protein levels according to rs4148382 genotype in controls. 4c: MRP1 protein levels according to rs4781699 genotype in COPD patients. 4d: MRP1 protein levels according to rs4781699 genotype in controls. N= number of individuals.

\begin{tabular}{|lcccc|}
\hline & FEV level & \multicolumn{2}{c}{ Inflammatory cells } & MRP1 protein \\
& & Bronchial biopsies & Induced sputum & level \\
\hline rs212093 & $\uparrow$ & $\downarrow$ & - & - \\
\hline rs4148382 & $\downarrow$ & - & $\uparrow$ & $\uparrow$ \\
\hline rs504348 & - & - & - & - \\
\hline rs4781699 & - & $\downarrow$ & - & $\downarrow$ \\
\hline rs35621 & - & - & - & - \\
\hline
\end{tabular}

Figure 5 Summary of MRP1 SNPs' associations for COPD patients. FEV ${ }_{1}=$ forced expiratory volume in one second; $M R P 1=$ multidrug resistanceassociated protein-1; = positive association; = negative association; - = no association. 


\section{Additional material}

\section{Additional file $1 M R P 1$ genetic variants, MRP1 protein levels and severity of COPD.}

Additional file 2 Figure S1: Linkage disequilibrium plot and correlation coefficients $\left(r^{2}\right)$ for 5 MRP1 polymorphisms genotyped in COPD patients $(n=110)$.

\section{Competing interests}

The authors declare that they have no competing interests.

\section{Authors' contributions}

SEB wrote the manuscript. SEB, JMV, and HMB analyzed the data. DSP, PSH, JMV HMB designed the GLUCOLD cohort study. JMV managed the data. HAS designed the Doetinchem cohort study and managed the data. SEB, DSP, MS, JMV, WT, HMB interpreted the data. SEB and BR performed immunohistochemistry. SEB and WT interpreted the results of the immunohistochemistry. All authors proposed corrections and approved the final version of the manuscript.

\section{Acknowledgements}

Members of the GLUCOLD Study Group: HF Kauffman, D de Reus, Department of Allergology; HM Boezen, DF Jansen, JM Vonk, Department of Epidemiology; MDW Barentsen, W Timens, M Zeinstra-Smit, Department of Pathology; AJ Luteijn, T van der Molen, G ter Veen, Department of General Practice; MME Gosman, NHT ten Hacken, HAM Kerstjens, MS van Maaren, DS Postma, CA Veltman, A Verbokkem, I Verhage, HK Vink-Kloosters, Department of Pulmonology; Groningen University Medical Center, Groningen, The Netherlands; JB SnoeckStroband, H Thiadens, Department. of General Practice; JK Sont, Department of Medical Decision Making; I Bajema, Department of Pathology; J Gast-Strookman, PS Hiemstra, K Janssen, TS Lapperre, KF Rabe, A van Schadewijk, J SmitBakker, J Stolk, ACJA Tire', H van der Veen, MME Wijffels and LNA Willems, Department of Pulmonology; Leiden University Medical Center, Leiden, The Netherlands; PJ Sterk, Department of Medical Centre, Amsterdam, The Netherlands, T Mauad, University of Sao Paulo, Sao Paulo, Brazil.

\section{Author Details}

1Department of Epidemiology, University Medical Center Groningen, University of Groningen, Groningen, the Netherlands, 2Department of Pulmonology University Medical Center Groningen, University of Groningen, Groningen, the Netherlands, ${ }^{3}$ Department of Pulmonology, Leiden University Medical Center, Leiden, the Netherlands, ${ }^{4}$ Julius Center for Health Sciences and Primary Care, University Medical Center Utrecht, the Netherlands and ${ }^{5}$ Department of Pathology, University Medical Center Groningen, University of Groningen, Groningen, the Netherlands

Received: 24 November 2009 Accepted: 20 May 2010 Published: 20 May 2010

\section{References}

1. Hogg JC, Chu F, Utokaparch S, Woods R, Elliott WM, Buzatu L, Cherniack RM, Rogers RM, Sciurba FC, Coxson HO, Paré PD: The nature of smallairway obstruction in chronic obstructive pulmonary disease. NEngl J Med 2004, 350:2645-2653

2. MacNee W: Pulmonary and systemic oxidant/antioxidant imbalance in chronic obstructive pulmonary disease. Proc Am Thorac Soc 2005, 2:50-60.

3. Sharom FJ: $A B C$ multidrug transporters: structure, function and role in chemoresistance. Pharmacogenomics 2008, 9:105-127.

4. Cole SP, Bhardwaj G, Gerlach JH, Mackie JE, Grant CE, Almquist KC, Stewart AJ, Kurz EU, Duncan AM, Deeley RG: Overexpression of a transporter gene in a multidrug-resistant human lung cancer cell line. Science 1992, 258:1650-1654.

5. Thomas GA, Barrand MA, Stewart S, Rabbitts PH, Williams ED, Twentyman PR: Expression of the multidrug resistance-associated protein (MRP) gene in human lung tumours and normal tissue as determined by in situ hybridisation. Eur J Cancer 1994, 30A:1705-1709.

6. Deen M van der, de Vries EG, Timens W, Scheper RJ, Timmer-Bosscha H, Postma DS: ATP-binding cassette (ABC) transporters in normal and pathological lung. Respir Res 2005, 6:59.
7. Deen M van der, Marks H, Willemse BW, Postma DS, Muller M, Smit EF, Scheffer GL, Scheper RJ, de Vries EG, Timens W: Diminished expression of multidrug resistance-associated protein 1 (MRP1) in bronchial epithelium of COPD patients. Virchows Arch 2006, 449:682-688.

8. Deen M van der, Timens W, Timmer-Bosscha H, Strate BW van der, Scheper RJ, Postma DS, de Vries EG, Kerstjens HA: Reduced inflammatory response in cigarette smoke exposed Mrp1/Mdr1a/1b deficient mice. Respir Res 2007, 8:49.

9. Deen $M$ van der, de Vries EG, Visserman H, Zandbergen W, Postma DS, Timens W, Timmer-Bosscha H: Cigarette smoke extract affects functional activity of MRP1 in bronchial epithelial cells. J Biochem Mol Toxicol 2007, 21:243-251.

10. Leschziner G, Zabaneh D, Pirmohamed M, Owen A, Rogers J, Coffey AJ, Balding DJ, Bentley DB, Johnson MR: Exon sequencing and high resolution haplotype analysis of $A B C$ transporter genes implicated in drug resistance. Pharmacogenet Genomics 2006, 16:439-450.

11. Siedlinski M, Boezen H, Boer JM, Smit HA, Postma DS: ABCC polymorphisms contribute to level and decline of lung function in two population-based cohorts. Pharmacogenet Genomics 2009, 19:675-684.

12. Lapperre TS, Snoeck-Stroband JB, Gosman MM, Stolk J, Sont JK, Jansen DF, Kerstjens HA, Postma DS, Sterk PJ: Dissociation of lung function and airway inflammation in chronic obstructive pulmonary disease. Am J Respir Crit Care Med 2004, 170:499-504.

13. Lapperre TS, Sont JK, van Schadewijk A, Gosman MM, Postma DS, Bajema IM, Timens W, Mauad T, Hiemstra PS: Smoking cessation and bronchial epithelial remodelling in COPD: a cross-sectional study. Respir Res 2007, 8:85.

14. Willemse BW, ten Hacken NH, Rutgers B, Postma DS, Timens W: Association of current smoking with airway inflammation in chronic obstructive pulmonary disease and asymptomatic smokers. Respir Res 2005, 6:38.

15. Celli BR, MacNee W: Standards for the diagnosis and treatment of patients with COPD: a summary of the ATS/ERS position paper. Eur Respir J 2004, 23:932-946.

16. Siedlinski M, Postma DS, van Diemen CC, Blokstra A, Smit HA, Boezen HM: Lung function loss, smoking, vitamin $C$ intake, and polymorphisms of the glutamate-cysteine ligase genes. Am J Respir Crit Care Med 2008, 178:13-19.

17. in 't Veen JC, de Gouw HW, Smits HH, Sont JK, Hiemstra PS, Sterk PJ, Bel EH: Repeatability of cellular and soluble markers of inflammation in induced sputum from patients with asthma. Eur Respir J 1996, 9:2441-2447.

18. Lapperre TS, Postma DS, Gosman MM, Snoeck-Stroband JB, ten Hacken $\mathrm{NH}$, Hiemstra PS, Timens W, Sterk PJ, Mauad T: Relation between duration of smoking cessation and bronchial inflammation in COPD. Thorax 2006, 61:115-121.

19. Wang Z, Wang B, Tang K, Lee EJ, Chong SS, Lee CG: A functional polymorphism within the MRP1 gene locus identified through its genomic signature of positive selection. Hum Mol Genet 2005 14:2075-2087

20. Loe DW, Deeley RG, Cole SP: Characterization of vincristine transport by the $M(r) 190,000$ multidrug resistance protein (MRP): evidence for cotransport with reduced glutathione. Cancer Res 1998, 58:5130-5136.

21. Renes J, de Vries EG, Nienhuis EF, Jansen PL, Muller M: ATP- and glutathione-dependent transport of chemotherapeutic drugs by the multidrug resistance protein MRP1. Br J Pharmacol 1999, 126:681-688.

22. Hipfner DR, Deeley RG, Cole SP: Structural, mechanistic and clinical aspects of MRP1. Biochim Biophys Acta 1999, 1461:359-376.

23. Leslie EM, Deeley RG, Cole SP: Toxicological relevance of the multidrug resistance protein 1, MRP1 (ABCC1) and related transporters. Toxicology 2001, 167:3-23.

24. O'Shaughnessy TC, Ansari TW, Barnes NC, Jeffery PK: Inflammation in bronchial biopsies of subjects with chronic bronchitis: inverse relationship of CD8+ T lymphocytes with FEV1. Am J Respir Crit Care Med 1997, 155:852-857.

25. Gosman MM, Willemse BW, Jansen DF, Lapperre TS, van Schadewijk A, Hiemstra PS, Postma DS, Timens W, Kerstjens HA: Increased number of Bcells in bronchial biopsies in COPD. Eur Respir J 2006, 27:60-64

26. Grashoff WF, Sont JK, Sterk PJ, Hiemstra PS, De Boer WI, Stolk J, Han J, van Krieken JM: Chronic obstructive pulmonary disease: role of bronchiolar mast cells and macrophages. Am J Pathol 1997, 151:1785-1790. 
27. Gosman MM, Boezen HM, van Diemen CC, Snoeck-Stroband JB, Lapperre TS, Hiemstra PS, Ten Hacken NH, Stolk J, Postma DS: A disintegrin and metalloprotease 33 and chronic obstructive pulmonary disease pathophysiology. Thorax 2007, 62:242-247.

28. Keatings VM, Collins PD, Scott DM, Barnes PJ: Differences in interleukin-8 and tumor necrosis factor-alpha in induced sputum from patients with chronic obstructive pulmonary disease or asthma. Am J Respir Crit Care Med 1996, 153:530-534

29. Langmann T, Mauerer R, Zahn A, Moehle C, Probst M, Stremmel W, Schmitz G: Real-time reverse transcription-PCR expression profiling of the complete human ATP-binding cassette transporter superfamily in various tissues. Clin Chem 2003, 49:230-238.

30. Brechot JM, Hurbain I, Fajac A, Daty N, Bernaudin JF: Different pattern of MRP localization in ciliated and basal cells from human bronchial epithelium. J Histochem Cytochem 1998, 46:513-517.

31. Scheffer GL, Pijnenborg AC, Smit EF, Muller M, Postma DS, Timens W, Valk $P$ van der, de Vries EG, Scheper RJ: Multidrug resistance related molecules in human and murine lung. J Clin Pathol 2002, 55:332-339.

32. Leier I, Jedlitschky G, Buchholz U, Keppler D: Characterization of the ATPdependent leukotriene C4 export carrier in mastocytoma cells. Eur J Biochem 1994, 220:599-606.

doi: 10.1186/1465-9921-11-60

Cite this article as: Budulac et al., Multidrug resistance-associated protein-1 (MRP1) genetic variants, MRP1 protein levels and severity of COPD Respiratory Research 2010, 11:60

Submit your next manuscript to BioMed Central and take full advantage of:

- Convenient online submission

- Thorough peer review

- No space constraints or color figure charges

- Immediate publication on acceptance

- Inclusion in PubMed, CAS, Scopus and Google Scholar

- Research which is freely available for redistribution

Submit your manuscript at www.biomedcentral.com/submit
Ciomed Central 